\title{
Desain Sistem Semantic Data Warehouse dengan Metode Ontology dan Rule Based untuk Mengolah Data Akademik Universitas XYZ di Bali
}

\author{
Made Pradnyana Ambara ${ }^{1}$, Made Sudarma ${ }^{2}$, dan I Nyoman Satya Kumara ${ }^{3}$
}

\begin{abstract}
Data warehouse which is generaly known as traditional data warehouse has some weaknesses on data modeling which has lead to the quality of the resulting data is not specific and ineffective. Semantic data warehouse system is the solution to solve the problems on traditional data warehouse because it has some advantages, such as: data quality management with the same data format to support a good OLAP report, along with a more effective performance with natural language keywords. The modeling of semantic data warehouse using ontology method produces logic resource description framework scheme (RDFS) model which later will be transformed into physical snowflake scheme. The academic report needed is produced through Kimball's nine step method and semanctic search using rule based method. The trial has been done with two trial methods namely black box testing and checklist questionnaire. From the findings of this research, it can be concluded that semantic data warehouse can help the academic data processing which produces good quality report to support decision making process.
\end{abstract}

Keywords - semantic data warehouse, OLAP, semantic search, ontology, rule based, Kimball's nine step method.

\begin{abstract}
Abstrak- Data warehouse pada umumnya yang sering dikenal data warehouse tradisional mempunyai beberapa kelemahan yang mengakibatkan kualitas data yang dihasilkan tidak spesifik dan efektif. Sistem semantic data warehouse merupakan solusi untuk menangani permasalahan pada data warehouse tradisional dengan kelebihan antara lain: manajeman kualitas data yang spesifik dengan format data seragam untuk mendukung laporan OLAP yang baik, dan performance pencarian informasi yang lebih efektif dengan kata kunci bahasa alami. Pemodelan sistem semantic data warehouse menggunakan metode ontology menghasilkan model resource description framework schema (RDFS) logic yang akan ditransformasikan menjadi snowflake schema. Laporan akademik yang dibutuhkan dihasilkan melalui metode nine step Kimball dan pencarian semantic menggunakan metode rule based. Pengujian dilakukan menggunakan dua metode uji yaitu pengujian dengan black box testing dan angket kuesioner cheklist. Dari hasil penelitian ini dapat disimpulkan bahwa sistem semantic data warehouse dapat membantu proses pengolahan data akademik yang menghasilkan laporan yang berkualitas untuk mendukung proses pengambilan keputusan.
\end{abstract}

\footnotetext{
${ }^{I}$ Mahasiswa, Jurusan Teknik Elektro dan Komputer, Fakultas Teknik, Universitas Udayana (e-mail: pradnyana_ambara@yahoo.com)

2, 3 Staff Pengajar, ,Jurusan Teknik Elektro dan Komputer Fakultas Teknik Universitas Udayana, Jln. Jalan Kampus Bukit Jimbaran 80361 INDONESIA (telp: 0361-703315; fax: 03614321; e-mail:msudarma@unud..ac.id,ins_kumara@yahoo.com)
}

Kata Kunci- semantic data warehouse, OLAP, pencarian semantik, ontology, rule based, nine step Kimball.

\section{PENDAHULUAN}

Berkembangnya aplikasi teknologi dan informasi saat ini telah menghasilkan kumpulan data yang besar. Menurut International Business Machines Corporatio (IBM) dalam situsnya, data yang besar dihasilkan oleh segala sesuatu di sekitar kita setiap saat. Kumpulan data yang besar dapat diimplementasikan pada Database Management System (DBMS) yang nantinya akan diolah untuk mendapatkan kebutuhan informasi yang cepat, akurat, dan menjadi suatu hal yang berharga [1]. Saat ini semua perguruan tinggi dituntut untuk memiliki keunggulan bersaing memanfaatkan semua sumber daya yang dimiliki. Sistem informasi adalah salah satu sumber daya yang dapat digunakan untuk meningkatkan keunggulan perguruan tinggi. Hambatan yang sering terjadi adalah setiap perguruan tinggi memiliki lebih dari satu sistem informasi dengan pengembangan DBMS tersendiri yang mengakibatkan integrasi laporan data akademik sulit diolah menjadi satu kesatuan informasi. Disamping itu juga data dari kegiatan akademik dari tahun ke tahun akan terus bertambah dan membuat ukuran database menjadi semakin besar. Adanya beragam sistem informasi dan jumlah data yang besar, maka perlu dikembangkan sebuah sistem data warehouse yang mampu mengintegrasikan data jumlah yang besar dari berbagai sistem informasi yang berbeda.

Data warehouse pada umumnya yang sering dikenal data warehouse tradisional mengelola model data terintegrasi serta juga mengolah data transaksional yang heterogen maupun yang homogen. Untuk membangun suatu data warehouse tradisional ada beberapa tahapan yang harus dilakukan, salah satu bagian dari data warehouse tradisional yang mempunyai peranan penting dalam menghasilkan suatu analisa data yang akurat adalah proses Extract Transform Loading (ETL). ETL adalah suatu proses mengambil dan mengirim data dari data sumber ke data warehouse [2]. ETL juga merupakan sekumpulan proses untuk mengambil dan memproses data dari satu atau banyak sumber menjadi sumber baru dan tidak hanya dari database Online Transaction Processing (OLTP) saja, tetapi bisa juga dari website, file teks, spreadsheet, email dan lainnya [3]. Proses ETL ini akan menghasilkan informasi yang terpusat dan terintegrasi dari penggabungan data dari berbagai sumber database OLTP. 
Data warehouse tradisional memiliki kelemahan pada teknik pemodelan data pada proses transform yang tidak menggambarkan secara detail sumber data yang diolah, sehingga mengakibatkan kualitas data yang dihasilkan untuk ditampung kedalam data warehouse menjadi tidak spesifik untuk menghasilkan laporan Online Analitical Processing (OLAP) yang mendukung proses pengambilan keputusan [4]. Untuk menghasilkan laporan OLAP dan data mart, pada data warehouse tradisional harus melalui beberapa proses tahapan lagi seperti landing zone, staging area, integrated store dan analytic layer didalam penyimpanan data warehouse, padahal sebelum data di load ke dalam data warehouse sudah melalui proses ETL untuk mendapatkan data yang berkualitas. Jadi pada data warehouse tradisional memiliki kesulitan pada proses integrasi data [5]. Pada data warehouse tradisional pencarian informasi akademik sebagian besar masih menggunakan pencarian dengan pemilihan parameter yang mengakibatkan proses pencarian tidak efektif dan terlalu banyak parameter yang ditampilkan. Dari berbagai kelemahan pada data warehouse tradisional, maka perlu dikembangkan sebuah sistem pengolahan data baru untuk menangani permasalahan pada data warehouse tradisional.

Beberapa penelitian yang berkaitan dengan data warehouse adalah penelitian yang menjelaskan perancangan data warehouse dengan menerapkan metode nine step Kimball [7]. Laporan OLAP yang dihasilkan adalah hanya profile mahasiswa serta desain multidimensional menggunakan star schema yang biasa digunakan pada data warehouse tradisional. Proses ETL hanya memindahkan data dari sumber OLTP ke database OLAP dan tidak melakukan proses transform secara detail. Pencarian OLAP menggunakan teknik pemilihan parameter yang mengakibatkan proses pencarian tidak efektif. Selanjutnya penelitian membangun data warehouse dengan metode ontology. Ontology menghasilkan desain data warehouse yang lebih terintegrasi dan berbasis pengetahuan, sehingga laporan OLAP yang dihasilkan lebih komplek. Desain ontology mengatasi kekurangan yang terdapat pada data warehouse tradisional [4]. Penelitian dengan metode ontology pada data warehouse menjadi komponen yang diperlukan untuk analisis laporan OLAP [8]. Penelitian selanjutnya adalah melakukan query semantic pada halaman web dengan media penyimpanan resource description framework (RDF), dimana proses query semantic pada relation database (RDB) sangat susah dilakukan. Maka dibuatkan relasi dari RDB ke RDF [9]. Proses query semantic akan menghasilkan informasi dengan menggunakan kata kunci bahasa alami yang memudahkan pengguna untuk mencari informasi yang dibutuhkan. Dari penelusuran kajian pustaka yang dilakukan, maka dikembangkan sebuah sistem semantic data warehouse untuk menangani permasalahan pada data warehouse tradisional.

Semantic data warehouse memiliki kelebihan pada manajeman kualitas data yang menghasilkan laporan OLAP yang berkualitas dengan format data yang seragam dari berbagai database OLTP yang berbeda menjadi database OLAP terpusat melalui proses ETL berbasis semantic. Pemodelan sistem semantic data warehouse menggunakan metode ontology dengan 7 tahapan menghasilkan model resource description framework schema (RDFS) logic yang nantinya akan ditransformasikan menjadi snowflake schema yang menjadi konseptual penyimpanan semantic data warehouse. Laporan akademik yang dibutuhkan oleh perguruan tinggi dihasilkan dari penerapan metode nine step Kimball yang langsung mengambil data yang sudah berkualitas dari database OLAP, sehingga laporan dihasilkan lebih berkualitas dari laporan yang dihasilkan oleh sistem informasi sebelumnya. Pencarian informasi berbasis semantic yang lebih efektif dengan menggunakan kata kunci bahasa alami Indonesia. Metode yang digunakan adalah rule based query dengan 7 aturan produksi berdasarkan identifikasi yang dilakukan oleh Andayani yang diterapkan pada penelitian [6]. Pencarian semantic dengan kata kunci bahasa alami membuat proses pencarian lebih efektif dibandingkan dengan pencarian menggunakan pemilihan parameter.

\section{SEMANTIC DATA WAREhouse}

Semantic Data Warehouse (SDWH) adalah tempat penyimpanan data yang cerdas yang diciptakan dalam proses ETL berbasis semantic. Memiliki sifat yang sangat dinamis karena kemampuannya untuk mengolah semantic ETL dan menerima update langsung secara terus menerus. Semantic data warehouse juga merupakan pengembangan data warehouse saat ini dimana informasi yang diberikan didefinisikan lebih bermakna yang memungkinkan perangkat lunak dan pengguna dapat bekerja sama. Semantic data warehouse bertujuan agar informasi pada data warehouse yang diekpresikan di dalam bahasa alami yang dimengerti manusia dan perangkat lunak (software). Dengan semantic data warehouse berbagai perangkat lunak akan mampu mencari, membagi, dan mengintegrasikan informasi dengan cara yang lebih mudah dan efektif.

\section{A. ETL Berbasis Semantic}

ETL adalah suatu proses mengambil dan mengirim data dari sumber data ke data warehouse [2]. Proses ETL berbasis semantic memiliki 3 tahapan, yaitu Extract, Transform dan Loading. Extract proses penentuan database OLTP sistem informasi yang akan digunakan sebagai sumber data bagi semantic data warehouse. Transform memilih field tertentu untuk dimasukkan ke dalam semantic data warehouse, menseragamkan format data dan mengidentifikasi nilai pada field menjadi bermakna. Selanjutnya melakukan proses transformasi dari OLTP fisik ke data model mapping dengan pendekatan ontology dan rule based yang menghasilkan bentuk model RDFS logic. Dari RDFS logic ini akan ditransformasikan kebentuk SDWH fisik dengan model dimensional snowflake schema. Proses yang terakhir adalah loading, memasukkan data yang sudah berkualitas ke dalam semantic data warehouse.

\section{B. Metode Ontology dan Rule Based}

Metode ontology digunakan untuk pemodelan bentuk dari konseptual data warehouse yang akan dirancang. Metode ontology ini memiliki beberapa tahapan (rule based) didalam 
perancangan [10], diantaranya (1) Penentuan konsep domain, (2) Penentuan daftar terminologi, (3) Definisi kelas dan struktur hirarki, (4) Relasi kelas diagram, (5) Definisi property dari kelas, (6) Konstrain property, (7) Menentukan instance. Aturan atau rule merupakan sebuah konsep yang menjadi acuan pada suatu model ontology serta pada proses pencarian informasi dengan kata kunci menggunakan bahasa alami (natural language) Indonesia.

Ontology rule based digunakan untuk mengatur relasi atau hubungan antar elemen-elemen penyusun ontology seperti relasi antar class, relasi class dengan data type, relasi antar instance dalam suatu class ataupun instance antar class, sedangkan query rule based menjadi acuan pada proses pencarian informasi berbasis semantic. Tipe query yang digunakan untuk acuan implementasi ini dengan penyusunan aturan produksi (production rule). Berdasarkan identifikasi yang telah dilakukan Andayani yang digunakan pada penelitian [6].

\section{Metode Nine Step Kimball}

Metodologi yang digunakan untuk menghasilkan laporan OLAP yang baik dari semantic data warehouse yaitu dengan penerapan metodologi sembilan langkah atau tahap (Nine-Step Methodology Kimball) yang diimplementasikan pada penelitian [7].

Metode nine step Kimball ini akan menghasilkan laporan akademik yang dibutuhkan oleh perguruan tinggi XYZ di Bali, seperti laporan penerimaan mahasiswa baru, laporan profile, nilai dan status akademik mahasiswa, laporan data profile dosen beserta staf pegawai. Laporan yang dihasilkan nantinya akan digunakan untuk pengambilan keputusan serta kelengkapan administrasi akreditasi perguruan tinggi.

\section{Pencarian Semantic}

Pencarian semantic merupakan sebuah cara untuk mendapatkan informasi dari sumber data yang besar (data warehouse) dengan menggunakan kata kunci (keyword) yang diekpresikan didalam bahasa alami (natural language) Indonesia yang dimengerti manusia dan dapat juga dimengerti, diinterpretasi oleh sistem aplikasi (software). Dengan demikian proses pencarian informasi pada data warehouse mampu memberikan hasil yang relevan dan efektif sesuai dengan yang diharapkan oleh pengguna.

\section{Desain Sistem SEMANTIC DATA WAREhOUSE}

\section{A. Gambaran Umum Sistem}

Gambaran umum sistem pada penelitian ini dibagi menjadi 3 bagian yaitu gambaran umum pembuatan desain proses semantic extract transform loading, semantic data warehouse, serta aplikasi OLAP berbasis web. Sumber data yang digunakan adalah OLTP dari 3 DBMS yang sama yaitu MySQL. Ketiga database OLTP tersebut adalah sistem informasi akademik, sistem informasi pegawai dan sistem informasi mahasisiswa. Data uji yang digunakan pada penelitian ini adalah data dummy dari tahun 2012 sampai
2015. Gambar 1: dibawah ini merupakan gambaran umum dari sistem semantic data warehouse.

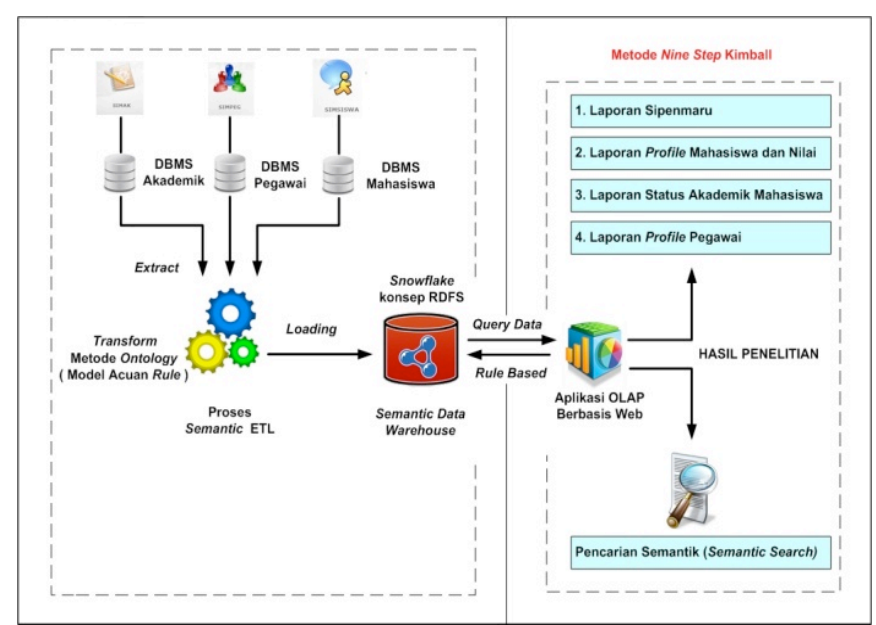

Gambar 1: Gambaran umum rancangan sistem

Dari rancangan sistem pada Gambar 1: terlihat sumber data yang diolah adalah 3 database OLTP sistem informasi yang berbeda pada perguruan tinggi XYZ di Bali. Proses semantic ETL akan mengintegrasikan sumber data OLTP yang beranekaragam menjadi data seragam yang terpusat pada penyimpanan semantic data warehouse.

\section{B. Pemodelan Ontology}

Pada perancangan desain sistem menggunakan metode ontology dengan rule (aturan) akan menghasilkan RDF schema logic (data model mapping) dan akan ditransformasikan menjadi desain multidimensional snowflake schema yang nantinya akan menjadi acuan konseptual penyimpanan database OLAP semantic data warehouse. Menurut Noy dan McGuinness ada 7 langkah atau aturan (rule) proses pemodelan ontology [10]. Gambar 2: dibawah ini merupakan flowchart proses pemodelan ontology.

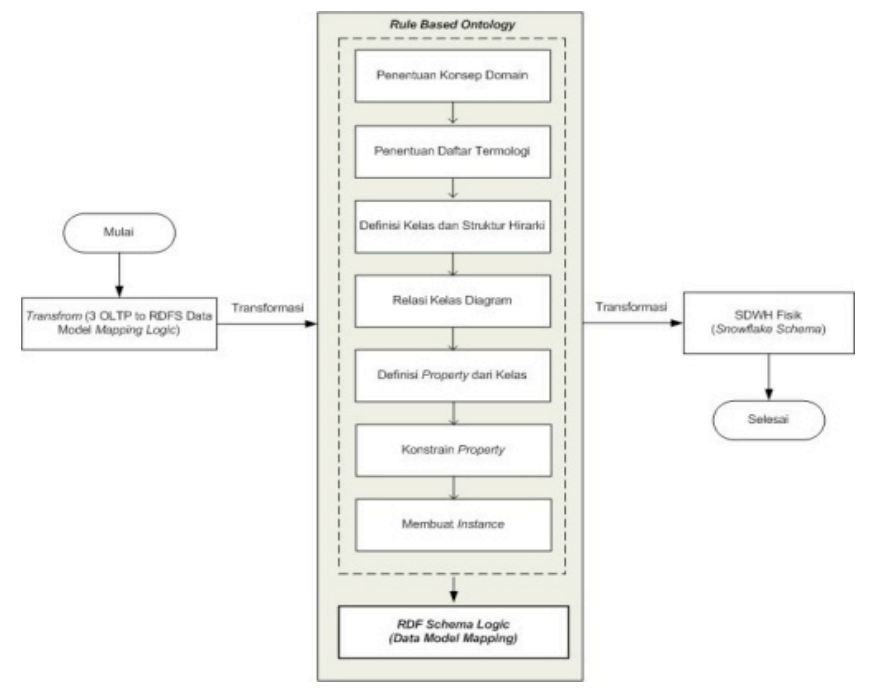




\section{Desain Multidimensional}

Pada semantic data warehouse semua tabel yang digunakan akan diimplementasikan dalam bentuk tabel dimensional dan tabel fakta. Tabel dimensional dan tabel fakta dirancang menggunakan snowflake schema seperti pada Gambar 3: dan Gambar 4: dibawah.

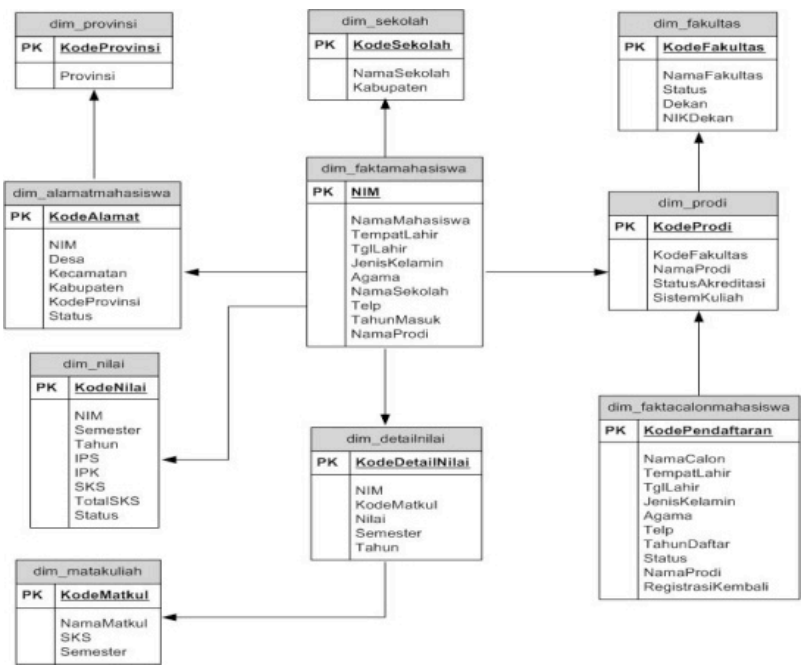

Gambar 3: Snowflake schema mahasiswa

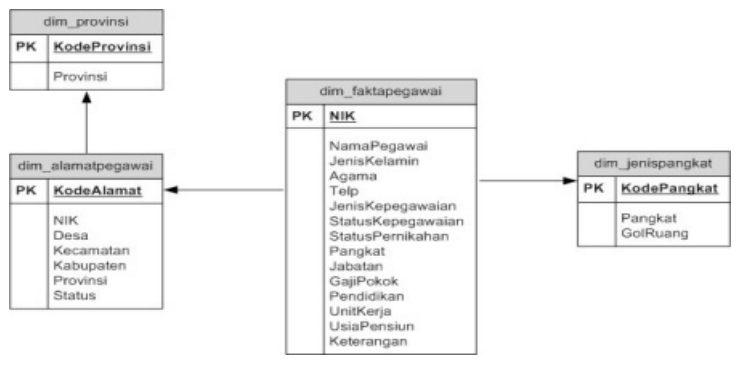

Gambar 4: Snowflake schema pegawai

\section{Perancangan Proses ETL Semantic}

Aplikasi ETL ini akan melakukan beberapa proses sesuai dengan fungsinya yaitu extract, transform dan loading. Gambar 5: dibawah merupakan flowchart dari proses ETL berbasis semantic.

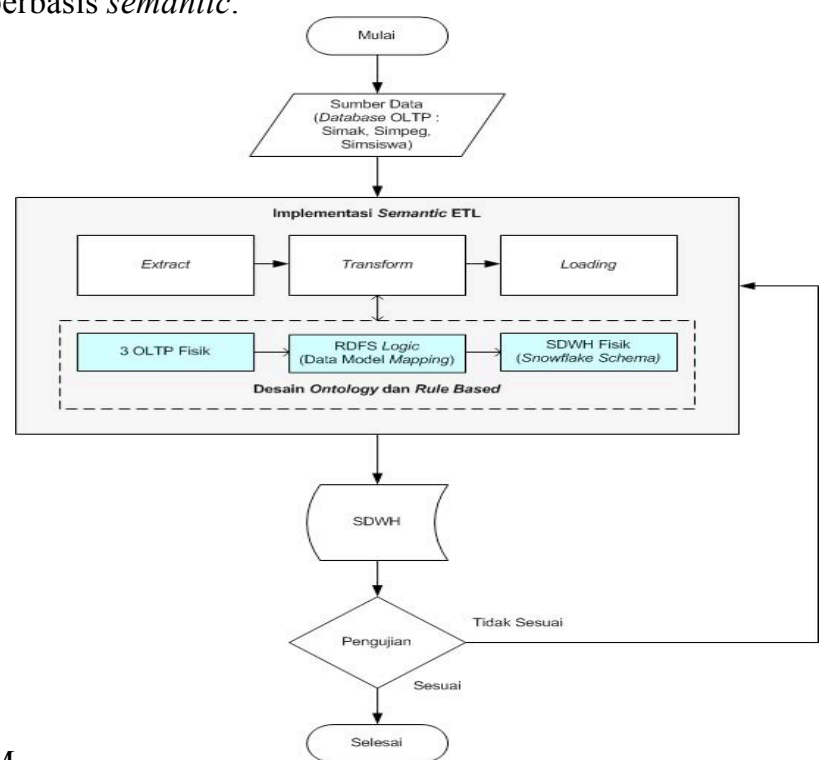

Gambar 5: Flowchart proses ETL berbasis semantic

\section{E. Perancangan Laporan OLAP}

Pada perancangan penggalian data (data mining) menjadi laporan OLAP pada semantic data warehouse ini, ada beberapa tahapan yang dilakukan untuk memperoleh hasil OLAP yang baik dengan penerapan nine step methodelogy Kimball seperti pada flowchart Gambar 6: dibawah ini.

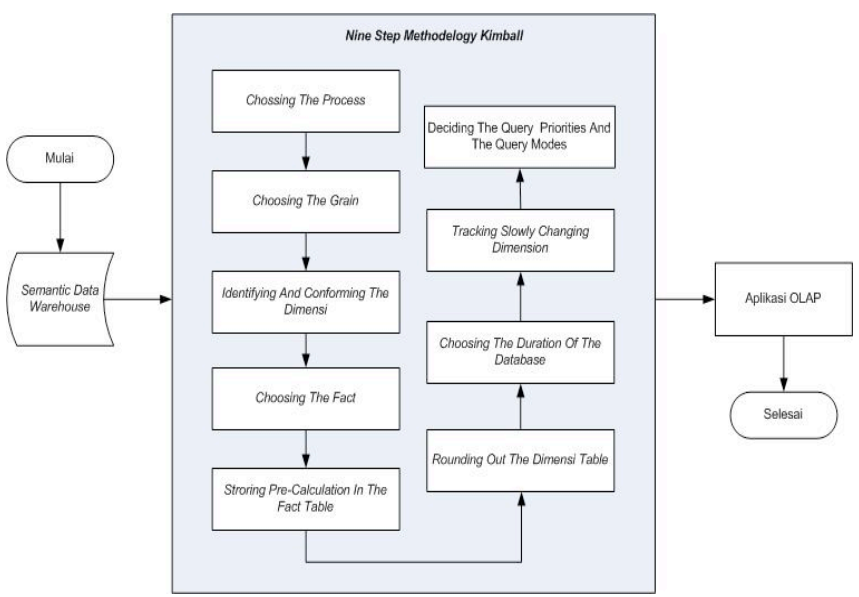

Gambar 6: Flowchart proses nine step Kimball

Laporan OLAP yang akan dihasilkan dari metode nine step Kimball adalah laporan akademik yang dibutuhkan oleh pihak perguruan tinggi. Adapun perincian laporan akademik seperti pada Tabel 1: dibawah ini.

TABEL I

HASIL LAPORAN OLAP

\begin{tabular}{|c|l|}
\hline No & \multicolumn{1}{|c|}{ Hasil Laporan dari Metodelogi Nine Step Kimball } \\
\hline 1 & $\begin{array}{l}\text { Laporan informasi tentang penerimaan mahasiswa baru (laporan } \\
\text { data sipenmaru) }\end{array}$ \\
\hline 2 & $\begin{array}{l}\text { Laporan profile mahasiswa dan laporan indek prestasi semester } \\
\text { (IPS) akademik mahasiswa }\end{array}$ \\
\hline 3 & Laporan status akademik mahasiswa \\
\hline 4 & Laporan profile pegawai dan dosen \\
\hline
\end{tabular}

\section{F. Perancangan Pencarian Semantic}

Perancangan pencarian semantic merupakan sebuah cara untuk mendapatkan informasi dari sumber data yang besar (data warehouse) dengan menggunakan kata kunci (keyword) bahasa alami (natural language) Indonesia. Perancangan prosesnya dapat dilihat pada flowchart Gambar 7: dibawah ini.

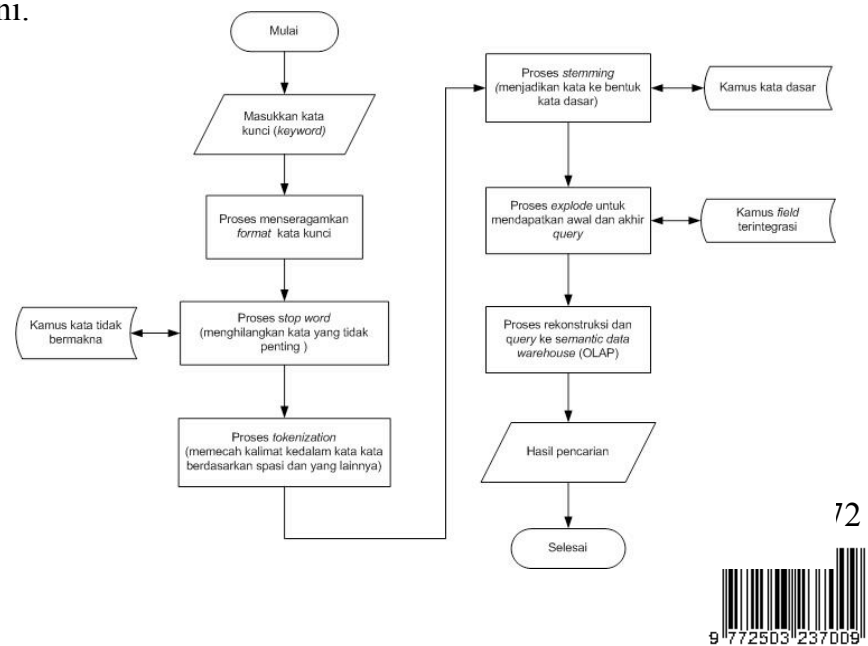


Gambar 7: Flowchart proses pencarian semantic

G. Metode Pengujian

Pengujian sistem adalah proses untuk memastikan semua fungsi pada sistem bekerja dengan baik serta mencari kesalahan yang mungkin terjadi pada sistem.

1. Pengujian Black Box

Pengujian black box merupakan tahap yang berfokus pada pernyataan fungsional perangkat lunak [12].

2. Pengujian Angket Kuesioner Cheklist

Kuesioner atau angket merupakan teknik pengumpulan data yang dilakukan dengan cara memberi seperangkat pertanyaan atau pernyataan tertulis kepada responden untuk dijawabnya [13].

\section{HASIL DAN ANALISA}

\section{A. Interface Sistem OLAP}

Tampilan desain interface sistem akan dibagi menjadi dua bagian yaitu sisi tampilan umum dan administrator. Tampilan umum seperti pada Gambar 8: merupakan tampilan interface pertama kali sistem pada saat dijalankan.

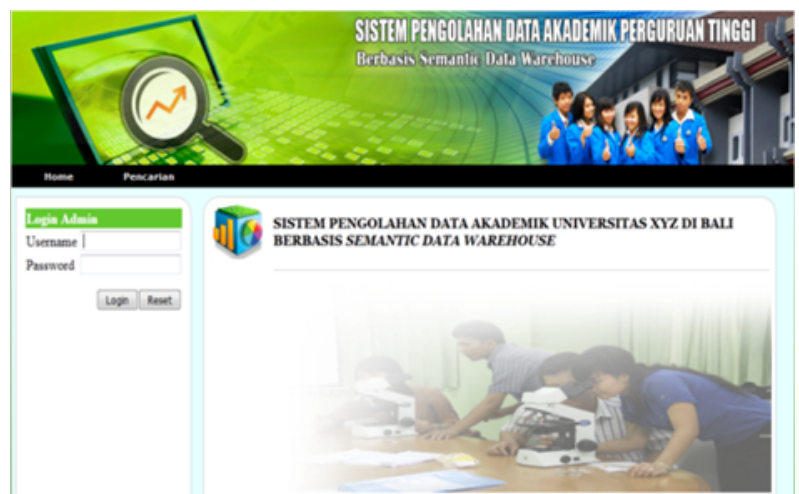

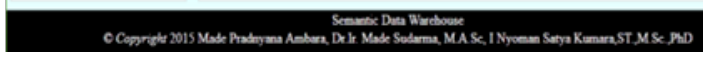

Gambar 8: Interface halaman umum

Selanjutnya bagian tampilan interface yang kedua adalah desain interface admin dimana user harus melakukan proses login terlebih dahulu. Pada Gambar 9: dibawah ini merupakan tampilan halaman admin, dimana proses pengolahan data akademik ada pada halaman ini. Sistem ini sudah dapat menampilkan hasil laporan seperti pada sistem informasi OLTP akademik, mahasiswa dan pegawai. Hasil laporannya lebih berkualitas dibandingkan dengan laporan yang dihasilkan oleh sistem informasi sebelumnya.

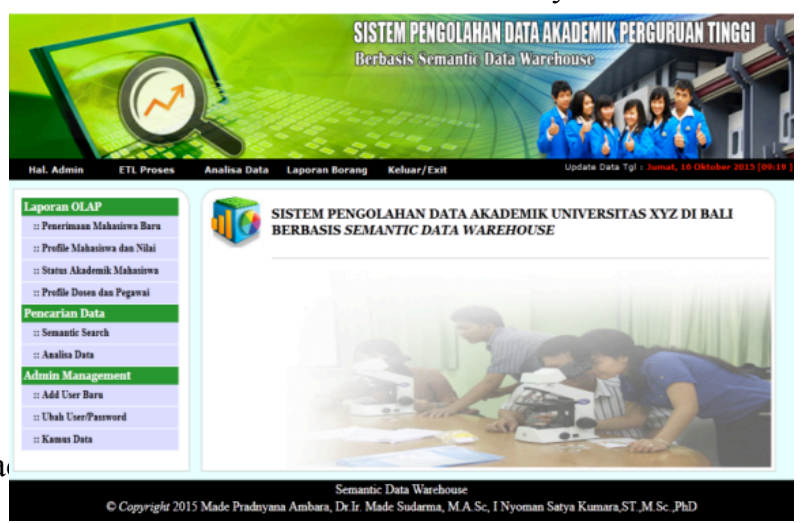

\section{Gambar 9: Interface halaman admin}

B. Proses Semantic ETL

Proses ETL berbasis semantic adalah proses dimana sistem melakukan tiga tahapan proses yaitu extract, transform dan loading dari 3 database OLTP sistem informasi ke database OLAP semantic data warehouse. Tampilan interface sistem progress-nya seperti pada Gambar 10: dibawah.

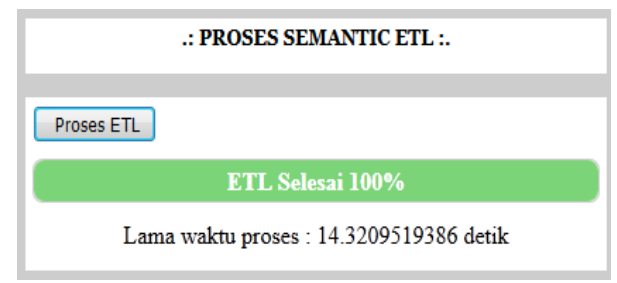

Gambar 10: Proses semantic ETL

Hasil dari proses ETL ini akan menghasilkan data berkualitas, seragam serta memiliki makna informasi yang dimengerti oleh user dan sistem. Gambar 11: merupakan sumber data mahasiswa dari database OLTP sistem informasi mahasiswa.

\begin{tabular}{|c|c|c|c|}
\hline Nama & JenisKelamin & Agama & TempatLahir \\
\hline i gusti agung putu eka putra & L & hindu & kuta \\
\hline ANSELMUS YEWA BANGA HORU & L & KATOLIK & Kuta \\
\hline vilda manuputty & $\mathrm{P}$ & Kisten & DENPASAR \\
\hline NI KOMANG DEWI DARMAYANI & $\mathrm{P}$ & hINDU & GIANYAR \\
\hline LOURDES MARIA DA COSTA & $P$ & Katolik & VIQUEQUE, TIMOR - LESTE \\
\hline I Putu Wahyu Kisna Pratama & L & Hindu & Bangli \\
\hline LUH KOMANG HANDANI & $\mathrm{P}$ & Hindu & GIANYAR \\
\hline Luh Komang Nischita Icha Indrayani & $\mathrm{P}$ & Hindu & Denpasar \\
\hline MARLON MANGGENA DJARAWULA & L & Kisten & Waingapu,Sumba Timur \\
\hline Siti Nurjannah & $\mathrm{P}$ & Islam & Denpasar \\
\hline IGEDE KRISNA SURYADI & L & Hindu & SINGARAJA \\
\hline RYAN RAMADHAN & L & ISLAM & DENPASAR \\
\hline I DEWA GEDE ARTA & L & Hindu & BANGLI \\
\hline Ni Luh Lili Kartini & $\mathrm{P}$ & Hindu & Gianyar \\
\hline Opik Listiani Candra Dewi & $\mathrm{P}$ & - & Badung \\
\hline NI GUSTI AYU PUTU INDAH UTAMI & $P$ & Hindu & Br. Pasekan \\
\hline
\end{tabular}

Gambar 11: Data dari sumber database OLTP mahasiswa

Data pada database OLTP ini tidak seragam, bisa dilihat pada field Gambar 11: penulisannya ada menggunakan huruf kapital, non kapital, menggunakan kode P atau L serta ada field yang value-nya kosong. Disinilah peranan ETL berbasis semantic untuk menseragamkan format yang berbeda-beda menjadi kesatuan yang dimengerti oleh sistem maupun user yang menggunakan. Hasil dari proses semantic ETL seperti tampilan pada Gambar 12: dibawah ini.

\begin{tabular}{|l|l|l|l|}
\hline Nama & JenisKelamin & Agama & TempatLahir \\
\hline I Gusti Agung Putu Eka Putra & Laki & Hindu & Kuta \\
\hline Anselmus Yewa Banga Horu & Laki & Katolik & Kuta \\
\hline Vilda Manuputty & Perempuan & Kisten & Denpasar \\
\hline Ni Komang Dewi Darmayani & Perempuan & Hindu & Gianyar \\
\hline Lourdes Maria Da Costa & Perempuan & Katolik & Viqueque Timor Leste \\
\hline I Putu Wahyu Kisna Pratama & Laki & Hindu & Bangli \\
\hline Luh Komang Handani & Perempuan & Hindu & Gianyar \\
\hline Luh Komang Nischita Icha Indrayani & Perempuan & Hindu & Denpasar \\
\hline Marton Manggena Djarawula & Laki & Kisten & Waingapu Sumba Timur \\
\hline Siti Nurjannah & Perempuan & Islam & Denpasar \\
\hline IGede Kisna Suryadi & Laki & Hindu & Singaraja \\
\hline Ryan Ramadhan & Laki & Islam & Denpasar \\
\hline I Dewa Gede Arta & Laki & Hindu & Bangli \\
\hline Ni Luh Lili Kartini & Perempuan & Hindu & Gianyar \\
\hline Opik Listiani Candra Dewi & Perempuan & Tidak Teridentifikasi & Badung \\
\hline Ni Gusti Ayu Putu Indah Utami & Perempuan & Hindu & Br Pasekan \\
& p-ISSN: $1693-2951 ;$ e-ISSN: 2503-2372 & \\
& & & \\
& & & \\
& & &
\end{tabular}


Gambar 12: Data hasil proses semantic ETL

Data yang dihasilkan sudah seragam, serta lebih bermakna sehingga menghasilkan laporan OLAP yang berkualitas.

\section{Laporan dan Analisa OLAP}

Perancangan aplikasi laporan OLAP ini sebagai hasil dari kebutuhan yang diperlukan oleh pihak perguruan tinggi. Hasil laporan ini diambil dari sumber database OLAP yang kualitas datanya yang sudah melalui proses semantic ETL dan proses pengambilan datanya sudah melalui tahapan nine step Kimball, sehingga menghasilkan laporan yang baik. Adapun laporan yang dihasilkan salah satunya adalah laporan OLAP penerimaan mahasiswa baru seperti pada Gambar 13: dibawah.

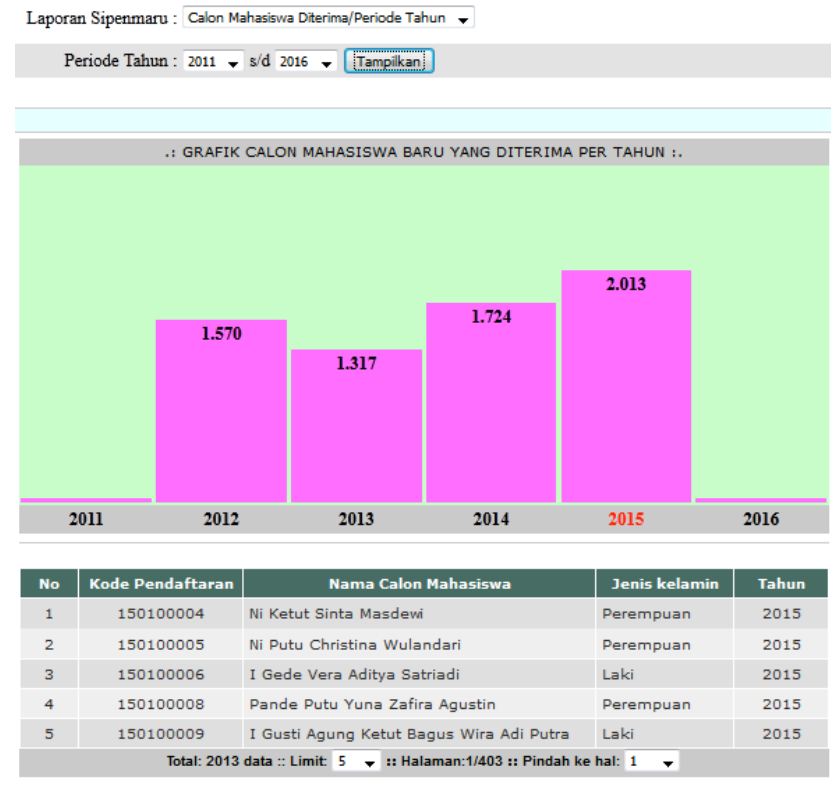

Cetak Data

Gambar 13: Hasil laporan OLAP sipenmaru

Dari laporan OLAP penerimaan mahasiswa baru pada Gambar 12: diatas, sistem yang dibuat bisa menganalisis pertumbuhan penerimaan mahasiswa baru tiap periode tahun. Proses analisa berdasarkan rekapitulasi persentase pertumbuhan jumlah mahasiswa baru yang diterima pada perguruan tinggi tiap tahunnya. Sistem akan menampilkan rata-rata dari persentase pertumbuhan penerimaan mahasiswa baru dari range periode yang dipilih seperti pada Gambar 14: berikut ini.

Analisa Sipenmaru : Mahasiswa Baru Diterima/Tahun .

Dari Tahun : 2012 sampai $2015-$ Analisa

\begin{tabular}{|c|c|c|c|c|c|}
\hline No & Tahun & Juml & ah Mahasiswa & Pertumbuhan (\%) & Analisis \\
\hline 1 & 2012 & 1.570 & Mahasiswa & $0 \%$ & Data Awal \\
\hline 2 & 2013 & 1.317 & Mahasiswa & $-19.21 \%$ & Menurun \\
\hline 3 & 2014 & 1.724 & Mahasiswa & $23.61 \%$ & Meningkat \\
\hline 4 & 2015 & 2.013 & Mahasiswa & $14.36 \%$ & Meningkat \\
\hline & \multicolumn{3}{|c|}{ Rata-Rata Pertumbuhan Tiap Tahun } & $\begin{array}{l}=18.75 \%: 3 \\
=6.25 \%\end{array}$ & Meningkat \\
\hline
\end{tabular}

Gambar 14: Laporan rekapitulasi analisis sipenmaru

Selain itu juga, ada salah satu profile mahasiswa yang akan dianalisa adalah rekapitulasi asal sekolah SMA mahasiswa diurutkan berdasarkan asal sekolah yang paling banyak. Ini bertujuan supaya pihak manajeman perguruan tinggi bisa mengetahui dan menganalisa dari sekolah mana yang terbanyak mahasiswanya berasal. Hasil rakapitulasinya seperti Gambar15: berikut ini.

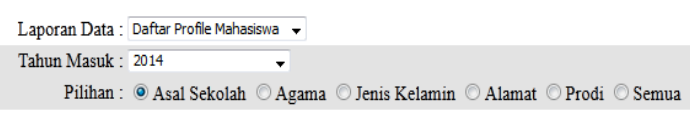

\begin{tabular}{|c|l|l|l|l|}
\hline No & \multicolumn{1}{|c|}{ Asal Sekolah } & \multicolumn{1}{|c|}{ Kota } & Jumlah Mahasiswa & Detail \\
\hline 1 & SMAN 2 Mengwi Badung & Badung & 23 Orang & Detail \\
\hline 2 & SMA Dwijendra Denpasar & Denpasar & 19 Orang & Detail \\
\hline 3 & SMKN 1 Denpasar & Denpasar & 17 Orang & Detail \\
\hline 4 & SMAN 1 Denpasar & Denpasar & 15 Orang & Detail \\
\hline 5 & SMAN 2 Denpasar & Denpasar & 14 Orang & Detail \\
\hline 6 & SMK Rekayasa Denpasar & Denpasar & 12 Orang & Detail \\
\hline 7 & SMAN 6 Denpasar & Denpasar & 12 Orang & Detail \\
\hline 8 & SMAN 8 Denpasar & Denpasar & 10 Orang & Detail \\
\hline 9 & SMAN 1 Kuta Utara & Badung & 9 Orang & Detail \\
\hline 10 & SMAN 1 Sukawati & Gianyar & 8 Orang & Detail \\
\hline
\end{tabular}

Gambar 15: Laporan rekapitulasi asal sekolah

\section{Pencarian Semantic}

Perancangan pencarian semantic ini bertujuan untuk menampilkan data yang dibutuhkan oleh pihak perguruan tinggi, dimana kata kunci yang dimasukkan berupa bahasa alami (natural language) Indonesia. Pada desain pencarian semantic disiapkan hanya satu text field yang menerima masukkan kata kunci dari pengguna, tampak pada Gambar 16: dibawah ini.

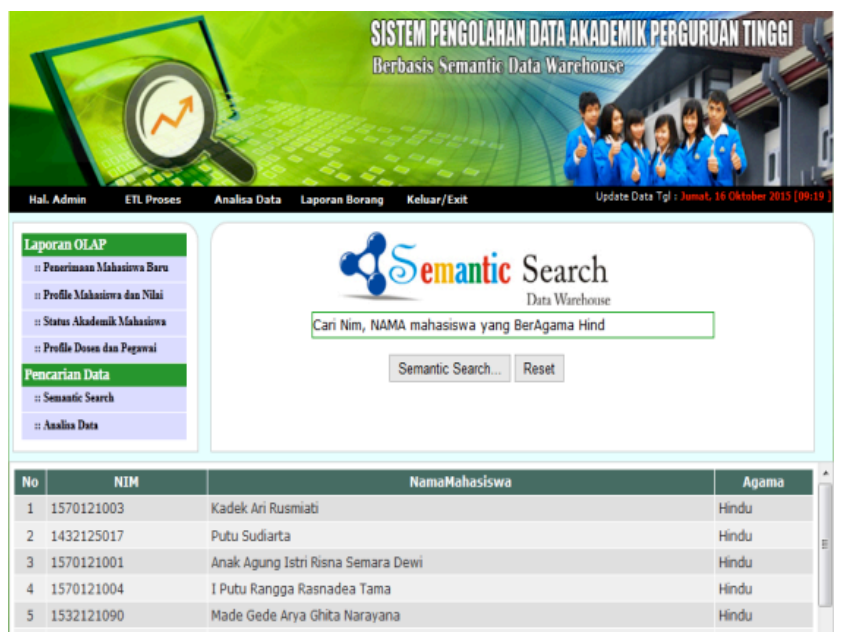

Gambar 16: Interface pencarian semantic

Kelebihan pencarian semantic dibandingkan dengan pencarian dengan pemilihan parameter adalah pencarian semantic lebih efektif dan jauh lebih efesien didalam mencari informasi yang dibutuhkan. 


\section{E. Pengujian Sistem}

Pengujian fungsional untuk desain sistem semantic data warehouse untuk mengolah data akademik pada penelitian ini menggunakan dua metode pengujian yaitu black box testing dan angket kuesioner cheklist.

1. Pengujian Black Box Testing

Pengujian dilakukan oleh 10 orang tester yang memiliki kemampuan dibidang programming yang memfokuskan pada fungsional kinerja sistem. Salah satu contoh dari pengujian black box testing seperti pada Tabel 2: dibawah ini.

TABEL II

CONTOH Pengujian Black Box Testing

\begin{tabular}{|l|l|l|c|}
\hline No & Skenario pengujian & Hasil yang diharapkan & Hasil pengujian \\
\hline 1 & $\begin{array}{l}\text { Menjalankan proses } \\
\text { semantic ETL ETL } \\
\text { dengan memilih } \\
\text { button Proses ETL }\end{array}$ & $\begin{array}{l}\text { STL yaitu Extract, } \\
\text { Transform dan Loading } \\
\text { dengan menampilkan } \\
\text { progress bar 0 - 100\% }\end{array}$ & Tidak Sesuai \\
\hline 2 & $\begin{array}{l}\text { Dst...26 skenario pengujian fungsional sistem. Jumlah skenario } \\
\text { pengujian tergantung dari ruang lingkup sistem yang dirancang. }\end{array}$ \\
\hline
\end{tabular}

Kesimpulan pengujian black box testing dengan 10 responden programmer, bahwa sistem yang dirancang $100 \%$ bekerja dengan baik sesuai fungsional sistem seperti dilihat pada Tabel 3: berikut ini.

TABEL III

Hasil PENGUJian BLACK Box Testing

\begin{tabular}{|c|l|l|}
\hline No & Daftar Proses Pengujian & Kesimpulan \\
\hline 1 & Proses login & Otorisasi sistem bekerja dengan baik \\
\hline 2 & Proses semantic ETL & Otorisasi sistem bekerja dengan baik \\
\hline 3 & Proses laporan OLAP & Otorisasi sistem bekerja dengan baik \\
\hline 4 & Proses pencarian semantic & Otorisasi sistem bekerja dengan baik \\
\hline 5 & Proses admin management & Otorisasi sistem bekerja dengan baik \\
\hline 6 & Proses logout & Otorisasi sistem bekerja dengan baik \\
\hline
\end{tabular}

2. Pengujian Angket Kuesioner Cheklist

Pengujian dilakukan oleh 15 orang pegawai yang mengerti masalah laporan akademik. Salah satu contoh dari pengujian angket kuesioner seperti pada Tabel 4: dibawah ini.

TABEL IV

CONTOH PENGUJian ANGKET KuESIONER CHEKLIST

\begin{tabular}{|c|c|c|c|}
\hline No & Skenario pengujian & Hasil proses & Hasil analisa \\
\hline 1 & $\begin{array}{l}\text { Menampilkan daftar } \\
\text { calon mahasiswa } \\
\text { baru yang diterima } \\
\text { periode tahun } 2014 \\
\text { sampai } 2015\end{array}$ & $\begin{array}{l}\text { Sistem menampilkan } \\
\text { hasil laporan penerimaan } \\
\text { calon mahasiswa baru } \\
\text { yang diterima tahun } \\
2014 \text { sampai } 2015 \text {. Data } \\
\text { tahun } 2014 \text { sebanyak } \\
1.724 \text { mahasiswa dan } \\
\text { tahun } 2015 \text { sebanyak } \\
2.013 \text { mahasiswa. }\end{array}$ & $\begin{array}{c}\sqrt{ } \text { Data Sesuai } \\
\text { Tidak Sesuai }\end{array}$ \\
\hline 2 & \multicolumn{3}{|c|}{$\begin{array}{l}\text { Dst...18 skenario pengujian hasil laporan. Jumlah skenario pengujian } \\
\text { hasil laporan tergantung dari ruang lingkup laporan yang dibutuhkan. }\end{array}$} \\
\hline
\end{tabular}

Kesimpulan pengujian ini dengan 15 responden pegawai, bahwa laporan yang dihasilkan $100 \%$ data sesuai dengan laporan pada 3 sistem informasi OLTP, dimana kualitas data laporan OLAP semantic data warehouse lebih baik dari laporan sistem informasi OLTP sebelumnya (perbandingan kualitas data dapat dilihat pada Gambar 11: dan Gambar 12:). Kesimpulan pengujian pada Tabel 5: berikut ini.

TABEL V

Hasil Pengujian ANGKet Kuesioner CheKLIS

\begin{tabular}{|c|l|c|}
\hline No & \multicolumn{1}{|c|}{ Daftar Proses Pengujian } & Kesimpulan \\
\hline 1 & Laporan sipenmaru & Hasil laporan sesuai \\
\hline 2 & Laporan profile mahasiswa dan nilai & Hasil laporan sesuai \\
\hline 3 & Laporan status akademik mahasiswa & Hasil laporan sesuai \\
\hline 4 & Laporan profile pegawai & Hasil laporan sesuai \\
\hline 5 & Pencarian informasi & Hasil laporan sesuai \\
\hline
\end{tabular}

Pengujian hasil kesesuaian pencarian informasi untuk memastikan data yang dihasilkan sesuai dengan harapan dan sesuai dengan kebutuhan. Tabel 6: dibawah ini adalah kesimpulan hasil pengujian pencarian semantic dengan daftar kata kunci yang beragam yang dimasukkan dengan penerapan 7 pola aturan.

TABEL VI

Hasil PENGUJian PENCARIAN SEMANTIC

\begin{tabular}{|c|c|c|c|}
\hline Pola & Kata Kunci & Tampil Data & Kesimpulan \\
\hline 1 & $\begin{array}{l}\text { Tampilkan Nama } \\
\text { Mahasiswa }\end{array}$ & $\mathrm{Ya}$ & Hasil data sesuai \\
\hline 2 & $\begin{array}{l}\text { Tampilkan NIM,Nama } \\
\text { Mahasiswa }\end{array}$ & $\mathrm{Ya}$ & Hasil data sesuai \\
\hline 3 & $\begin{array}{l}\text { Cari Nim, NAMA } \\
\text { mahasiswa yang } \\
\text { BerAgama Hind }\end{array}$ & $\mathrm{Ya}$ & Hasil data sesuai \\
\hline 4 & $\begin{array}{l}\text { Cari nama mahasiswa } \\
\text { yang berjenis kelamin } \\
\text { laki dan beralamat dari } \\
\text { kota TABAN }\end{array}$ & $\mathrm{Ya}$ & Hasil data sesuai \\
\hline 5 & $\begin{array}{l}\text { Tampilkan nama, agama } \\
\text { mahasiswa yang } \\
\text { beralamat dari desa } \\
\text { panjer atau desa baturiti }\end{array}$ & $\mathrm{Ya}$ & Hasil data sesuai \\
\hline 6 & $\begin{array}{l}\text { Tampilkan nama } \\
\text { mahsiswa yang } \\
\text { beragama bukan Hindu }\end{array}$ & $\mathrm{Ya}$ & Hasil data sesuai \\
\hline 7 & $\begin{array}{l}\text { Tampilkan NIM, Nama } \\
\text { mahasiswa yang berjenis } \\
\text { kelamin Laki dan } \\
\text { beragama bukan Islam }\end{array}$ & $\mathrm{Ya}$ & Hasil data sesuai \\
\hline
\end{tabular}

Ada beberapa pengujian yang sudah dilakukan dengan memasukkan kata kunci pencarian dengan berbagai kondisi kalimat yang beragam seperti kata kunci yang menggunkan huruf kapital maupun non kapital dan ada kata kunci yang tidak lengkap dimasukkan. Disinilah peranan dari teknologi semantic untuk menseragamkan kata kunci yang memiliki format yang berbeda-beda (beranekaragam format tulisan) sehingga antara user dan perangkat lunak saling memahami serta dapat merekonstruksi kata yang hurufnya ada hilang, sehingga sistem menampilkan hasil yang dibutuhkan oleh pihak user.

\section{KESIMPULAN}


Kesimpulan dari penelitian ini bahwa sistem semantic data warehouse yang dirancang untuk mengolah data akademik perguruan tinggi dari tiga sumber database OLTP berhasil dibuat dengan menerapakan metode ontology dan rule based. Data yang sudah tersimpan dalam database OLAP semantic data warehouse merupakan data dengan format yang sudah seragam dan lebih bermakna, sehingga laporan yang dihasilkan dari penerapan metode nine step Kimball adalah laporan data akademik yang berkualitas untuk mendukung proses pengambilan keputusan. Aplikasi pencarian semantic yang dirancang berhasil mencari informasi yang dibutuhkan dengan menggunakan kata kunci bahasa alami (natural language ) Indonesia.

Unjuk kerja dari sistem semantic data warehouse yang sudah diuji dari segi fungsional sistem dengan metode black box testing, bahwa sistem yang dibuat $100 \%$ bekerja dengan baik sesuai dengan fungsinya. Laporan OLAP yang dihasilkan sudah diuji dari segi kesuaian dengan metode angket kuesioner cheklist 100\% data sesuai dengan laporan yang dihasilkan dari sistem informasi OLTP, dimana kualitas laporan OLAP semantic data warehouse lebih baik dibandingkan dengan laporan sistem informasi OLTP, serta pencarian informasi dengan kata kunci bahasa alami lebih efektif dan efesien dibandingkan dengan pencarian menggunakan pemilihan parameter.

\section{REFERENSI}

[1] Darudiato, S. 2010. Perancangan Data Warehouse Penjualan untuk Mendukung Kebutuhan Informasi Eksekutif Cemerlang Skin Care.UPN Veteran Yogyakarta, ISSN:1979-2328.

[2] Rainardi, V. 2008. Building a Data Warehouse With Example in SQL Server. United States of America: Apress.

[3] Mulyana. 2014. Pentaho: Solusi Open Source untuk Membangun Data Warehouse. Yogyakarta: Andi

[4] Pardillo, J., Mazon, J.N. 2011. Using Ontologies For The Design Of Data Warehouse. (IJDMS), Vol. 3, No. 2, May 2011.

[5] Kimball, R., Caserta, J. 2011, The Data Warehouse ETL Toolkit: Practical Techniques for Extracting, Cleaning, Conforming, and Delivering Data, John Wiley \& Sons

[6] Wibisono, S. 2013. Aplikasi Pengolah Bahasa Alami untuk Query Basis Data Akademik dengan Format Data XML. Jurnal Teknologi Informasi DINAMIK, Volume 18 No 1, Januari 2013, ISSN: $0854-$ 9524.

[7] Yohanlis, S. 2014. Data Warehouse Design Of Students Profile From XYZ University. Jurnal Teknik dan Ilmu Komputer, Vol. 03, No. 10 Apr - Jun 2014

[8] Thenmozhi1, M., Vivekanandan, K. 2013. A Tool For Data Warehouse Multidimensional Schema Design Using Ontology. (IJCSI), ISSN:1694-0814, Vol.10, Issue 2, No. 3, March 2013.

[9] Banu, A., Fatima, S.S., Khan, K.U.R. 2011. Semantic - Based Querying Using Ontology in Relational Database of Library Management System.(IJWesT) Vol. 2, No. 4, October 2011.

[10] Andri. 2012. Penerapan Bahasa Alami Sederhana Pada Online Public Access Catalog (OPAC) Berbasis Web Semantic. SemnasIF 2012, ISSN:1979-2328.

[11] Turban, S, Delen, King. 2011. Business Intelligence Dashboard. Yogyakarta. Indonesia.

[12] Luqman. 2012. "Aplikasi Web Sistem Informasi Penjualan Pada Khazanah Ponsel Yogyakarta". Yogyakarta: Sekolah Tinggi Manajemen Informatika Dan Komputer Amikom

[13] Sugiyono. 2013. Metode Penelitian Pendidikan Pendekatan Kuantitatif, Kualitatif, dan $R \&$ D. Bandung: Alfabeta. 